\title{
PENGARUH HARGA DAN KELENGKAPAN PRODUK TERHADAP \\ KEPUTUSAN PEMBELIAN KONSUMEN ONLINE SHOP \\ TOKOPEDIA.COM DI FAKULTAS EKONOMI \\ JURUSAN MANAJEMEN UNIVERSITAS \\ NEGERI MEDAN
}

\author{
Dita Amanah \\ Adinda Ayu Layla \\ Fakultas Ekonomi UNIMED \\ ditamnh@yahoo.com \\ adindaayulayla@gmail.com
}

\begin{abstract}
This study aims to determine the effect of price and completeness of products on consumer purchasing decisions online shop Tokopedia.com at Faculty of Economics Department of Management State University of Medan. The sample in this study were all students of the Faculty of Economics Department of Management University of Medan which is still active and shopping in Tokopedia.com as many as 122 respondents. The test used is the test data quality and classical assumption. The hypothesis test uses multiple linear regression analysis, $F$ test and $t$ test. Validity of test results obtained $r_{\text {adding }}>r_{\text {table }}$ for each item reliability test questions and questionnaires obtained a Cronbach alpha of each variable is 0.805 for the variable $X_{1}, 0.759$ for variable $X_{2}$ and 0.794 for the variable $Y$. This value is greater than the level that is significantly rtable 0.361. The data analysis of each variable regression equation $Y=$ $8.986+0.143 x_{1}+0.178 x_{2}+e$. Retrieved $R^{2}$ of 0.487 , which is means the $X_{1}$ and $X_{2}$ explain the effect on variable $Y$ of $48.7 \%$ while the remaining $51.3 \%$ described variables out of the company. The resulting partial test each independent variables affect the dependent variable with research significance less than 0.05 , and the results of the test-simultaneous calculation of 4.156 with Ftable 3.07, which is means $F_{\text {adding }}>$ $F_{\text {table }}$ with a level of significant $(\alpha) 0,000<0,05$, which is means that the hypothesis is accepted that price and completeness of the product together significantly influence on consumer purchase decisions online shop Tokopedia.com at Faculty of Economics Department of Management State University of Medan.
\end{abstract}

Keywords: Price, Products Completeness, Purchase Decisions.

\section{PENDAHULUAN}

Perkembangan teknologi ternyata berdampak luas terhadap berbagai aspek.

Tidak terkecuali perkembangan dunia bisnis dan pemasaran. Internet sudah menjadi salah satu sarana utama bagi para pemasar dalam upaya mempromosikan produk mereka. Dikarenakan fenomena pengguna internet sangat berkembang pesat dan telah menjadi gaya hidup 
masyarakat sekarang ini. Hal tersebut tentu memunculkan ide para pebisnis untuk menjadikan pengguna internet menjadi sasaran potensial untuk menjual atau mempromosikan produknya secara online.

Salah satu sistem internet yang berkembang pesat adalah sistem penjualan secara elektronik (e-commerce) yang sangat populer dikalangan penggunanya. Melalui sistem ini para pemasar berusaha merangsang para pengguna internet agar tertarik membeli produk mereka. Pemasar harus mampu mempengaruhi para konsumen agar memilih produk mereka mengingat banyaknya pesaing yang juga menjalankan bisnis yang sama. Menurut Peter (2005:162), mengemukakan keputusan pembelian adalah proses pengintegrasian yang mengkombinasikan pengetahuan untuk mengevaluasi dua atau lebih perilaku alternatif dan memilih salah satu diantaranya.

Tokopedia.com merupakan salah satu e-commerce terkemuka di indonesia. Tokopedia.com didirikan pada tanggal 17 Agustus 2009 dengan visi membangun indonesia lebih baik melalui internet. Tujuan didirikannya Tokopedia.com adalah sebagai sarana pemasar untuk memasarkan atau mempromosikan produk mereka di media online. Namun Tokopedia.com harus siap bersaing dengan kompetitor berat mereka semisal Lazada.com, Kaskus, BukaLapak, dan lain sebagainya yang juga berjalan di bisnis yang sama. Oleh karena itu pihak Tokopedia perlu memperhatikan faktorfaktor yang dapat menjadi daya tarik para pengguna internet agar tertarik mengunjungi situs Tokopedia.com. Salah satu faktor yang menjadi daya tarik bagi konsumen adalah harga yang kompetitif. Perbandingan harga yang disesuaikan dengan manfaat yang diperoleh konsumen dapat menjadi senjata ampuh bagi pihak Tokopedia.com untuk bersaing memenangkan hati para konsumen.

Tokopedia.com merupakan salah satu mall online di Indonesia yang mengusung model bisnis marketplace. Sejak diluncurkan hingga akhir 2015, layanan dasar Tokopedia bisa digunakan oleh semua orang secara gratis. Dengan visi untuk "Membangun Indonesia yang Lebih Baik Lewat Internet", Tokopedia memiliki program untuk mendukung para pelaku Usaha Mikro Kecil dan Menengah (UMKM) dan perorangan untuk mengembangkan usaha mereka dengan memasarkan produk secara online. Tokopedia.com resmi diluncurkan ke publik pada 17 Agustus 2009 di bawah 
naungan PT Tokopedia yang didirikan oleh William Tanuwijaya dan Leontinus Alpha Edison pada 6 Februari 2009. Sejak resmi diluncurkan, PT Tokopedia berhasil menjadi salah satu perusahaan internet Indonesia dengan pertumbuhan yang sangat pesat. Jenis-jenis produk yang jual oleh Tokopedia.com adalah seperti Elektronik, Fashion, Otomotif, Perawatan Bayi, Alat-alat rumah tangga dan lainnya

\section{Harga}

Harga adalah suatu nilai tukar yang bisa disamakan dengan uang atau barang lain untuk manfaat yang diperoleh dari suatu barang atau jasa bagi seseorang atau kelompok pada waktu tertentu dan tempat tertentu. Istilah harga digunakan untuk memberikan nilai finansial pada suatu produk barang atau jasa. Biasanya penggunaan kata harga berupa digit nominal besaran angka terhadap nilai tukar mata uang yang menunjukkan tinggi rendahnya nilai suatu kualitas barang atau jasa. Kottler, Keller dan Armstrong (2012:383) mengemukakan bahwa harga merupakan satu-satunya bauran elemen pemasaran yang menghasilkan pendapatan, elemen-elemen lainnya menimbulkan biaya. Harga juga merupakan salah satu elemen bauran pemasaran yang paling fleksibel (harga dapat diubah dengan cepat).

Menurut Tjiptono

$(2008: 151)$ menyebutkan bahwa harga merupakan satu-satunya unsur bauran pemasaran yang memberikan pemasukan atau pendapatan bagi perusahaan. Sedangkan pendapat lain menurut Kotler dan Amstrong (2008:345), harga adalah sejumlah uang yang ditagihkan para pelanggan untuk memperoleh manfaat dari memiliki atau menggunakan suatu produk atau jasa.

Menurut Hasan (2008:59) Harga adalah segala bentuk biaya moneter yang dikorbankan oleh konsumen untuk memperoleh, memiliki, memanfaatkan sejumlah kombinasi dari barang serta pelayanan dari suatu produk. Menurut Swastha (2007:147) Harga adalah jumlah uang (ditambah beberapa barang kalau mungkin) yang dibutuhkan untuk mendapatkan sejumlah kombinasi dari barang beserta pelayanannya.

Menurut Kotler dan Armstrong (2008:278) ada tiga indikator yang mencirikan harga, yaitu:

1. Ketergantungan harga

2. Kesesuaian harga dengan kualitas produk

3. Daya saing harga 


\section{Kelengkapan Produk}

Kelengkapan produk merupakan sesuatu yang dapat ditawarkan kedalam pasar untuk diperhatikan, dimiliki, dipakai, atau dikonsumsi sehingga dapat memuaskan keinginan atau kebutuhan (Kotler dan Armstrong, 2008:345).

Selanjutnya Kotler (2008:347) dalam penjelasannya menyatakan bahwa "kelengkapan produk adalah tersedianya semua jenis produk yang ditawarkan untuk dimiliki, dipakai atau dikonsumsi oleh konsumen yang dihasilkan oleh suatu produsen". Sedangkan pendapat lain menurut Engels (2007:258) "kelengkapan produk merupakan hal yang menyangkut kedalaman, luas dan kualitas produk yang ditawarkan juga ketersediaan produk tersebut setiap saat di toko".

Raharjani mengemukakan variabel kelengkapan produk meliputi keragaman barang yang dijual di pasar swalayan dan ketersediaan barang-barang tersebut di pasar swalayan. Indikator dari kelengkapan produk, yaitu:

1. Kelengkapan jenis produk yang ditawarkan.

2. Kelengkapan produk merk yang ditawarkan.

3. Kelengkapan produk variasi ukuran yang ditawarkan
4. Kelengkapan produk variasi kualitas produk yang ditawarkan

\section{Keputusan Pembelian}

Keputusan pembelian dalam arti yang umum adalah "a decision is the selection of an option from two or more alternative choices" yaitu suatu keputusan seseorang dimana dia memilih salah satu dari beberapa alternatif pilihan yang ada. Keputusan pembelian konsumen adalah tahap dalam proses pengambilan keputusan pembeli dimana konsumen benar - benar membeli produk (Kotler dan Armstrong, 2004-226).

Menurut Schiffman

(2008:485) mendefinisikan keputusan merupakan seleksi terhadap dua pilihan alternatif atau lebih, dengan perkataan lain, pilihan alternatif harus tersedia bagi seseorang ketika mengambil keputusan. Sebaliknya, jika konsumen tersebut tidak mempunyai alternatif untuk memilih dan benar-benar terpaksa melakukan pembelian tertentu dan tindakan tertentu, maka keadaan tersebut bukan merupakan suatu keputusan.

Pendapat lain menurut Peter (2005:162), mengemukakan keputusan pembelian adalah proses pengintegrasian yang mengkombinasikan pengetahuan untuk mengevaluasi dua atau lebih 
perilaku alternatif dan memilih salah satu diantaranya.

Menurut Kotler (2005:64) indikator keputusan pembelian meliputi :

1. Budaya

Kebudayaan merupakan faktor penentu yang paling dasar dari keinginan perilaku seseorang. Dimana terdapat dua variabel didalamnya, yaitu subbudaya dan kelas sosial.

2. Sosial

Perilaku konsumen juga dipengaruhi oleh faktor sosial seperti kelompok referensi, peran, status sosial, dan keluarga

3. Pribadi

Keputusan pembelian juga dipengaruhi oleh karakteristik pribadi. Faktor pribadi meliputi usia dan tahap dalam siklus hidup pembeli; pekerjaan dan keadaan ekonomi; kepribadian dan konsep diri; serta gaya hidup dan nilai

4. Psikologi

Psikologi adalah perilaku seseorang baik yang tampak maupun yang tidak tampak. Yang merupakan perwujudan kejiwaan seseorang.

5. Bauran pemasaran

Bauran pemasaran adalah kombinasi dari empat variabel atau kegiatan yang merupakan inti dari sistem pemasaran perusahaan. Swastha (2005:237) Mendefenisikan variabel bauran pemasaran sebagai berikut :

a. Produk

Produk adalah segala sesuatu yang dapat ditawarkan ke pasar untuk memperoleh perhatian, permintaan, pemakaian atau konsumsi yang dapat memenuhi kebutuhan meliputi benda fisik, jasa, tempat, ide, atau gagasan kualitas pelayanan produk kepada konsumen perlu dilakukan oleh perusahaan, hal ini diarahkan agar produk yang diterima sesuai dengan apa yang diharapkan oleh pelanggan yang ujungnya konsumen akan merasa loyal akan produk yang dihasilkan oleh perusahaan.

b. Harga

harga adalah jumlah uang (kemungkinan ditambah beberapa barang) yang dibutuhkan untuk mendapatkan sejumlah kombinasi dengan beserta pelayanannya

c. Distribusi

Saluran distribusi adalah unit organisasi seperti produsen, pedagang besar, pengecer, dan sebagainya yang melaksanakan semua kegiatan yang diperlukan untuk menyampaikan suatu produk 
dari produsen ke penjual kepada konsumen.

d. Promosi

Promosi adalah semua jenis kegiatan pemasaran yang ditujukan untuk mendorong permintaan.

Ada beberapa faktor yang dapat dijadikan landasan dalam mengamati proses terjadinya keputusan konsumen dalam menetapkan pilihan dalam rangka memenuhi kebutuhan dan keinginannya. Yaitu keputusan pembelian, keputusan pembelian adalah suatu keputusan seseorang untuk memilih antara suatu produk dengan produk lain yang sejenis. Banyak faktor yang dapat mempengaruhi keputusan konsumen dalam membeli produk, diantaranya adalah faktor harga. Dimana bagi konsumen harga merupakan salah satu bahan pertimbangan yang penting untuk membeli produk pada suatu toko atau perusahaan, karena harga suatu produk mempengaruhi persepsi konsumen mengenai produk tersebut. Dalam penentuan harga setiap toko atau perusahaan harus lah berhati-hati dan mempunyai strategi khusus untuk menarik minat para konsumennya. Kelengkapan produk merupakan hal yang menyangkut kedalaman, luas dan kualitas produk yang ditawarkan juga ketersediaan produk tersebut setiap saat di toko, ketersediaan menjadi faktor penting karena para konsumen cenderung akan kehilangan kepercayaan ketika suatu tempat atau toko mengalami kekosongan persediaan atas produk yang diinginkan oleh konsumen.

Dari gambaran yang dikemukakan, maka dapat diungkapkan suatu kerangka konseptual yang berfungsi sebagai penuntun alur pikir dan dasar penelitian ini yang dapat digambarkan sebagai berikut :

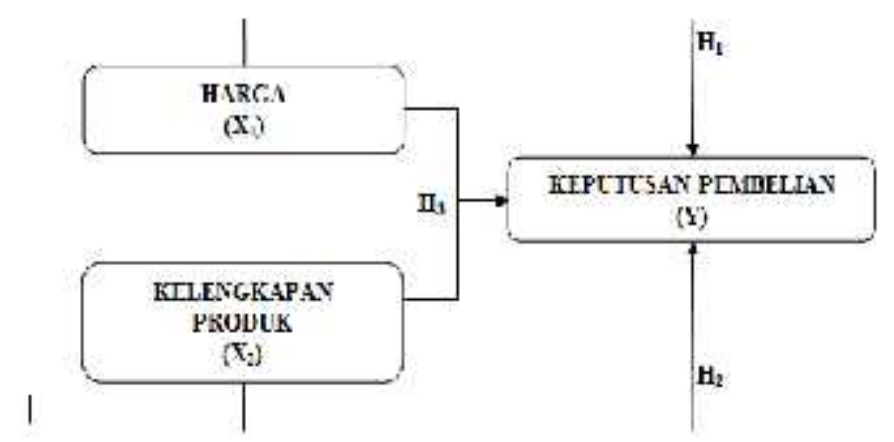

\section{Metodologi Penelitian}

Penelitian ini dilakukan di Fakultas Ekonomi Jurusan Manajemen Universitas Negeri Medan yang beralamat di Jl. Williem Iskandar Pasar V Kotak Pos No. 1589 Medan 20221, Medan. Waktu penelitian dilakukan selama bulan Februari.

Sampel yang diambil dalam penelitian adalah konsumen yang melakukan pembelian sebesar 122 orang responden. Metode penelitian sampel 
menggunakan metode Purposive Sampling.

Sedangkan variabel dalam penelitian ini adalah :

a. Variabel Bebas $\left(\mathrm{X}_{1}\right)$ : Harga

b.Variabel Bebas $\left(\mathrm{X}_{2}\right)$ : Kelengkapan

Produk

c.Variabel Terikat (Y) : Keputusan

Pembelian

Data yang digunakan dalam penelitian ini adalah data primer yaitu data yang diperoleh dari responden pada lokasi penelitian.Untuk memperoleh data yang digunakan penulis menggunakan alat pengumpul data melalui :

1.Observasi

Yaitu pengumpulan data dengan mengadakan pengamatan langsung terhadap obyek yang diteliti. Adapun obyek yang diteliti dalam penelitian ini adalah konsumen Brastagi Supermarket Cambridge Medan Dengan tujuan mengetahui bagaimana pengaruh kepercayaan dan lingkungan fisik terhadap kepuasan konsumen.

\section{Wawancara}

Metode ini digunakan untuk melengkapi data yang belum terungkap dalam angket, mengenai gambaran konsumen dalam melakukan proses belanja, dengan menggunakan pedoman sejumlah pertanyaan untuk memperoleh data yang menunjang penelitian ini.

3. Kuesioner

Merupakan metode pengumpulan data melalui penyebaran pertanyaan yang diajukan sehubungan dengan materi penelitian kepada responden yang telah terpilih. Skala yang dipakai dalam penelitian ini adalah skala Likert dengan menggunakan ukuran Interval.

Sebelum melakukan analisis data, terlebih dahulu dilakukan uji Validitas dan Reliabilitas, Uji validitas dan reabilitas dilakukan untuk menguji apakah kuesioner layak digunakan sebagai instrumen penelitian atau tidak.

Teknik analisis data yang digunakan dalam penelitian ini adalahanalisis regresi linear berganda.

Untuk menguji kebenaran hipotesis pertama digunakan uji $\mathrm{F}$ yaitu untuk menguji keberartian/signifikansi regresi secara keseluruhan

\section{Hasil Dan Pembahasan Penelitian}

Dalam penelitian ini yang menjadi sampel atau responden adalah mahasiswa jurusan manajemen fakultas ekonomi universitas negeri medan. Dengan sampel dalam penelitian ini yang berjumlah 122 orang dengan identifikasi sebagai berikut 


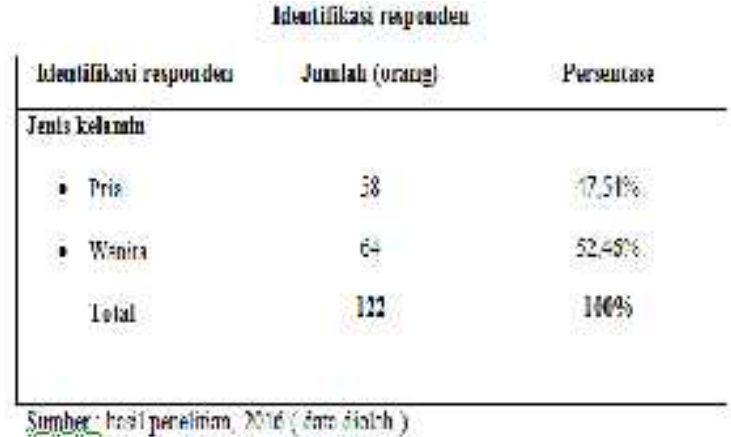

Model analisis yang digunakan dalam penelitian ini adalah regresi berganda. Analisis regresi berganda dilakukan untuk mengetahui seberapa besar pengaruh variabel independen (Harga dan Kelengkapan Produk) terhadap variabel dependen (Keputusan Pembelian). Analisis ini dibantu dengan program pengolahan data Statistical Packages for Social Science 22,0 (SPSS).

Model regresi linear berganda dengan 1 variabel dependen (Y) yaitu variabel Keputusan Pembelian dan 2 variabel independen (Xi) yaitu variabel Harga $\left(\mathrm{X}_{1}\right)$ dan Kelengkapan Produk $\left(\mathrm{X}_{2}\right)$ adalah sebagai berikut :

\section{$\hat{\mathbf{Y}}=a+b 1 X 1+b 2 X 2+e$}

Untuk menguji hipotesis yang menyatakan terdapat pengaruh Harga $\left(\mathrm{X}_{1}\right)$ dan Kelengkapan Produk $\left(\mathrm{X}_{2}\right)$ terhadap Keputusan Pembelian (Y) digunakan analisis regresi berganda. Berdasarkan hasil perhitungan diperoleh hasil persamaan regresi ganda adalah sebagai berikut :

Chefildents"

\begin{tabular}{|c|c|c|c|c|c|c|c|c|}
\hline \multirow{2}{*}{\multicolumn{2}{|c|}{ Model }} & \multicolumn{2}{|c|}{ 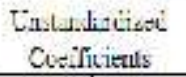 } & \multicolumn{2}{|l|}{$\begin{array}{l}\text { 8lindir dieal } \\
\text { Cueficieals }\end{array}$} & \multirow[b]{2}{*}{$\mathrm{Sig}$} & \multicolumn{2}{|c|}{$\begin{array}{l}\text { Collisonity } \\
\text { Statistic: }\end{array}$} \\
\hline & & $\mathrm{R}$ & $\begin{array}{l}\text { Sto } \\
\text { Frent }\end{array}$ & Font: & $T$ & & Tnitranes: & VTF \\
\hline \multirow[t]{3}{*}{1} & (C)uslant) & 3.986 & 2.335 & & 3.707 & .105 & & \\
\hline & IIALGGA Xl & .43 & .031 & .166 & 2.856 & $\operatorname{kol}$ & 985 & 1.013 \\
\hline & $\begin{array}{l}\text { KEIENGKWPAN } \\
\text { PRODUR X2 }\end{array}$ & $\therefore / \mathrm{s}$ & 19: & 214 & 2.449 & osj & $\$ 85$ & 2.011 \\
\hline
\end{tabular}

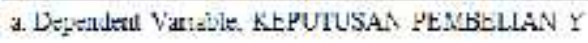

Dari data hasil SPSS di atas dapat dijelaskan sebagai berikut :

$Y=8,986+0,143 X_{1}+0,178 X_{2}+e$

1. Konstanta sebesar 8,986 menyatakan bahwa jika tidak ada variabel $\mathrm{X}$, yaitu Harga dan Kelengkapan Produk maka Keputusan Pembelian adalah sebesar 8,986, dengan asumsi faktor lain konstan

2. Koefisien $X_{1}$ sebesar 0,143 menyatakan bahwa setiap terjadi kenaikan Harga akan mempengaruhi Keputusan Pembelian sebesar 0,143 dengan asumsi faktor lain konstan

3. Koefisien $\mathrm{X}_{2}$ sebessar 0,178, menyatakan bahwa setiap terjadi peningkatan Kelengkapan Produk akan mempengaruhi Keputusan Pembelian sebesar 0,178 dengan asumsi faktor lain konstan.

Pengujian hipotesis penelitian dilakukan untuk menguji ketiga hipotesis 
penelitian yang telah dipaparkan Dari tabel di atas maka dapat dijelaskan sebelumnya.Untuk mengetahui apakah bahwa :

variabel independen dalam model regresi berpengaruh terhadap variabel dependen, maka dilakukan pengujian dengan menggunakan uji $t$ ( $t$ test) dan uji $F(F$ test).

Uji statistik $\mathrm{t}$ dilakukan untuk menguji pengaruh dari variabel independen terhadap variabel dependennya secara individu. Hal ini dapat dilihat dari nilai signifikan $\mathrm{t}$ yang dihasilkan dari perhitungan. Apabila nilai signifikan $\mathrm{t}<$ tingkat signifikan $(0.05)$ maka variabel independen secara individu berpengaruh terhadap variabel dependennya, sebaliknya jika nilai signifikan $t>$ tingkat signifikansi $(0.05)$ maka variabel independennya secara individu tidak berpengaruh terhadap variabel dependennya. Berdasarkan hasil pengolahan SPSS versi 22.0 diperoleh hasil sebagai berikut :

\begin{tabular}{|c|c|c|c|c|c|c|}
\hline \multirow[b]{3}{*}{ Mrriel } & \multicolumn{4}{|c|}{ Coefficiens's' } & \multirow{2}{*}{\multicolumn{2}{|c|}{$\begin{array}{l}\text { Cedlinmaty } \\
\text { Stristic: }\end{array}$}} \\
\hline & \multicolumn{2}{|c|}{$\begin{array}{l}\text { Urstariardizo: } \\
\text { Cosäticients }\end{array}$} & $\begin{array}{l}\text { Stadardizsi } \\
\text { Cosffivarts }\end{array}$ & \multirow[b]{2}{*}{$T$} & & \\
\hline & B & $\begin{array}{l}\text { Stci } \\
\text { Frmer }\end{array}$ & B $=13$ & & Trlesane & $\mathrm{BF}$ \\
\hline (Constant) & 8.9806 & 1385 & & $3.57 \quad 105$ & & \\
\hline HARGA TI & $4<3$ & $0 \pi T$ & Iŕc & 155.5001 & $\$ 3$ & 9017 \\
\hline $\begin{array}{l}\text { KEIENGKAPAN } \\
\text { PRODOKX X }\end{array}$ & . 38 & WYI & {$[/ 4$} & $1.94 \pm$, tow2 & 503 & :.01 \\
\hline
\end{tabular}

a Depentex Variatle KEPLTUSEN PEMEEUIAN Y
1. Nilai $t$ hitung variabel Harga 1.856>dari $t_{\text {tabel }}$ yaitu 1,657 dan nilai signifikan $0.001<0,05$ Hal ini berarti hipotesis diterima yaitu : Harga secara parsial berpengaruh positif dan signifikan terhadap Keputusan Pembelian Konsumen Online Shop Tokopedia.com di Fakultas Ekonomi Jurusan Manajemen Universitas Negeri Medan.

2. Nilai t hitung variabel Kelengkapan Produk 1.949> dari $\mathrm{t}_{\text {tabel }}$ yaitu 1.657 dan nilai signifikan $0.003<0,05$. Hal ini berarti hipotesis diterima yaitu : Kelengkapan Produk secara parsial berpengaruh positif dan signifikan terhadap Keputusan Pembelian Konsumen Online Shop Tokopedia.com di Fakultas Ekonomi Jurusan Manajemen Universitas Negeri Medan

Pengaruh dari kedua variabel bebas secara serentak terhadap variabel terikat dapat dilihat dari hasil uji F. adapun syarat dari uji $F$ adalah jika $F_{\text {hitung }}>F_{\text {tabel }}$ maka Ho ditolak dan H1 diterima. Berdasarkan hasil pengujian statistik (Uji ANOVA/Uji F) dapat dilihat pada tabel output berikut : 


\begin{tabular}{|c|c|c|c|c|c|c|}
\hline \multicolumn{7}{|c|}{ ANOVA ${ }^{a}$} \\
\hline \multicolumn{2}{|c|}{ Model } & $\begin{array}{l}\text { Son of } \\
\text { Squares }\end{array}$ & d & $\begin{array}{l}\text { Kean } \\
\text { Sgueso }\end{array}$ & F & 5ig. \\
\hline 1 & Rsgresson & 131.692 & 2 & 55. 306 & 4.150 & $.00 f^{\circ}$ \\
\hline & Kestinl & 1885.173 & 111 & +2.3 & & \\
\hline & lota' & 20.2360 & 221 & & & \\
\hline
\end{tabular}

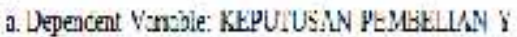

b. Precicors (Conster)], KELENGKAFAN PRODUK X2, HARGA X1

Pada tabel diatas diperoleh bahwa nilai $\mathrm{F}=4.156$ dengan tingkat signifikansi $0,000<0,05 . \quad F_{\text {tabel }}$ dapat dilihat pada table statistik (Terlampir) pada tingkat signifikansi 0,05 dengan df 1 $($ Jumlah variabel-1 $)=2$, dan df $2(n-k-1$ ) atau $122-2-1=119$ Setelah mengetahui $\mathrm{F}$ hitung, maka akan di bandingkan dengan $F_{\text {tabel }}$ dengan taraf kesalahan $5 \%$ adalah $=3,07$ maka $\mathrm{F}_{\text {hitung }}$ $=4,156>F_{\text {tabel }}(3,07)$. Dengan demikian, dapat ditarik kesimpulan koefisien arah regresi berganda pada taraf signifikan 0.05 yang artinya Harga dan Kelengkapan Produk secara bersamasama berpengaruh positif dan signifikan terhadap Keputusan Pembelian Konsumen Online Shop Tokopedia.com di Fakultas Ekonomi Jurusan Manajemen Universitas Negeri Medan.

Untuk mengetahui seberapa besar Persentase Pengaruh variabel bebas terhadap variabel terikat atau untuk melihat seberapa besar variabel bebas dapat menjelaskan pengaruhnya terhadap variabel terikat. Maka dilakukan pengujian koefisien determinasi $\left(\mathrm{R}^{2}\right)$ sehingga diperoleh hasil seperti tabel di bawah ini.

\section{Hasil Uji R}

Model Summary

\begin{tabular}{|l|c|rc|r|}
\hline Model & R & R Square & $\begin{array}{c}\text { Adjusted R } \\
\text { Square }\end{array}$ & $\begin{array}{l}\text { Std. Error of } \\
\text { the Estimate }\end{array}$ \\
\hline 1 & $.666^{z}$ & .487 & .472 & 2,503630 \\
\hline
\end{tabular}

a. Predictors: (Constant), KELENGKAPAN PRODUK X2, HARGA X1

Dari tabel output diatas dapat dilihat bahwa koefisien determinan $\left(\mathrm{R}^{2}\right)$ adalah sebesar 0,487. Nilai ini menunjukan bahwa variabel Keputusan Pembelian (Y) dipengaruhi oleh variabel Harga $\left(\mathrm{X}_{1}\right)$ Dan Kelengkapan Produk $\left(\mathrm{X}_{2}\right)$ secara bersama-sama sebesar $48,7 \%$ dan sisanya $51,3 \%$ dipengaruhi oleh Variabel lain yang tidak dibahas dalam penelitian ini.

Berdasarkan hasil penelitian bahwa nilai $\mathrm{R}^{2}$ sebesar 0,487 yang berarti variabel Harga dan Kelengkapan Produk memberikan pengaruh terhadap Variabel Keputusan Pembelian sebesar 48,7\%, Sedangkan sisanya 51,3\% dijelaskan oleh faktor lain diluar dari Variabel penelitian ini.

Jika ditinjau dari pengaruh secara parsial (Uji t), variabel Harga berpengaruh secara positif dan signifikan terhadap Keputusan Pembelian 
Konsumen Online Shop Tokopedia.com di Fakultas Ekonomi Jurusan Manajemen Universitas Negeri Medan, hal ini terlihat dari nilai signifikan $1,856>$ dari $\mathrm{t}$ tabel yaitu 1,657 dan nilai signifikan $0.001<$ 0,05 .

Variabel Kelengkapan Produk secara parsial berpengaruh secara positif dan signifikan terhadap Keputusan Pembelian Konsumen Online Shop Tokopedia.com di Fakultas Ekonomi Jurusan Manajemen Universitas Negeri Medan, hal ini terlihat dari nilai signifikan Kelengkapan Produk 1,949 > dari $\mathrm{t}_{\text {tabel }}$ yaitu 1,657 dan nilai signifikan $0.001<0,05$.

Dari hasil penelitian juga membuktikan Hipotesis diterima dengan adanya hasil secara simultan (uji F) yaitu $F_{\text {hitung }}=4,156>F_{\text {tabel }}(3,07)$, dengan demikian dapat ditarik kesimpulan koefisien arah regresi berganda pada taraf signifikan 0,05 yang artinya Harga dan Kelengkapan Produk berpengaruh positif dan signifikan terhadap Keputusan Pembelian Konsumen Online Shop Tokopedia.com di Fakultas Ekonomi Jurusan Manajemen Universitas Negeri Medan.

\section{Kesimpulan Dan Saran}

\section{Kesimpulan}

Berdasarkan hasil penelitian dan pembahasan, maka dapat diambil kesimpulan sebagai berikut :

1. Berdasarkan perhitungan uji hipotesis secara parsial (Uji t) terhadap variabel Harga, diperoleh $t_{\text {hitung }}>t_{\text {tabel }}$ dengan nilai $1,856>1,657$. Hal ini berarti variabel Harga berpengaruh positif dan signifikan terhadap Keputusan Pembelian.

2. Berdasarkan perhitungan uji hipotesis sacara parsial (Uji t) terhadap variabel Kelengkapan Produk, diperoleh $t_{\text {hitung }}>t_{\text {tabel }}$ dengan nilai $1,949>1,657$. Hal ini berarti variabel Kelengkapan Produk berpengaruh positif dan signifikan terhadap Keputusan Pembelian .

3. Dari hasil penelitian variabel Harga dan Kelengkapan Produk secara bersama-sama mempengaruhi Keputusan Pembelian Konsumen Online Shop Tokopedia.com di Fakultas Ekonomi Jurusan Manajemen Universitas Negeri Medan. Hal ini dapat dilihat dari hasil perhitungan uji-F sebesar 4,156 dengan $F_{\text {tabel }}$ 3,07 yang artinya $F_{\text {hitung }}$ $>\mathrm{F}_{\text {tabel}}$, menyatakan bahwa hipotesis diterima. 
4. Di peroleh oleh nilai $\mathrm{R}$ square $\left(\mathrm{R}^{2}\right)=$ 0,487 atau $48,7 \%$ yang artinya bahwa bahwa secara simultan Harga dan Kelengkapan Produk mempunyai pengaruh sebesar 48,7\% terhadap Keputusan Pembelian dan 51,3\% dipengaruhi oleh variabel lain di luar variabel yang diteliti.

\section{Saran}

Berdasarkan penelitian yang telah dilakukan, maka penulis mengemukakan beberapa saran, yaitu :

1. Toko elektronik di Tokopedia.com diharapkan dapat menetapkan harga yang sesuai dengan manfaat produk untuk menarik minat para konsumennya dalam melakukan keputusan pembelian secara online di tokopedia.com.

2. Toko elektronik di Tokopedia.com harus selalu melengkapi produkproduk mereka yang telah habis atau sold out. Karena kelengkapan produk akan mempengaruhi konsumen dalam melakukan keputusan pembelian secara online di tokopedia.com khususnya di toko elektronik.

3. Bagi Peneliti Selanjutnya

Peneliti selanjutnya dapat mengembangkan penelitian ini dengan melakukan penelitian pada faktor- faktor lain yang dapat memengaruhi keputusan pembelian seperti faktor keamanan, kemudahan, dan kepercayaan yang dapat mempengaruhi keputusan pembelian. Dengan demikian, peneliti selanjutnya dapat menganalisis faktor-faktor tersebut atau yang lain yang dapat mempengaruhi keputusan pembelian secara online di Tokopedia.com.

\section{DAFTAR PUSTAKA}

Enggel, James F dan Roger D Blacwel. 2007. Perilaku Konsumen Edisi Ke Enam. Jakarta. Binarupa Aksara.

Fatharani, Afrida, Nawazirul Lubis, dan Reni Shinta Dewi. 2013. "Pengaruh Gaya Hidup (Lifestyle), Harga (Price), dan kelompok referensi (Reference Group) terhadap Keputusan Pembelian Telepon Blackberry (Studi pada Mahasiswa Program S1 Angkatan 2009 Fakultas Ilmu Sosial dan Ilmu Politik Universitas Diponegoro)". Jurnal Ilmu Administrasi Bisnis, Vol. 2 No. 3, pp.1-20. Universitas Diponegoro

Hasan, Ali. 2008. Marketing. Yogyakarta: Med Press.

Hutasoit Melias Irma, 2014. "Pengaruh Kualitas Pelayanan dan Keragaman Produk terhadap Keputusan Pembelian secara online pada Mahasiswa Fakultas Ekonomi UNIMED”. Skripsi. 
Medan : Universitas Negeri Medan.

J. Lenzun, Jessica., D.D Massie, James dan Adare, Decky. 2014. "Pengaruh Kualitas Produk, Harga dan Promosi Terhadap Kepuasan Pelanggan Kartu Prabayar Telkomsel'. Jurnal $E M B A$,Vol. 2, No. 3, September 2014, hal 1237-1245.

Khalis. Muhammad. 2015. "Pengaruh Kelengkapan Produk dan Kualitas Pelayanan terhadap Keputusan Pembelian Konsumen di Alfamidi Jalan Bromo" Skripsi. Medan : Universitas Negeri Medan.

Kotler, Philip. 2008. Manajemen Pemasaran. Jilid 2. Jakarta: Bumi Aksara

\section{Manajemen}

Pemasaran. Edisi Revisi Jilid 1. Jakarta: Penerbit PT. Index.

Kotler, Philip. \& Keller, Amstrong. 2012. Marketing Management. New Jersey : Prentice Hall.

Kotler, Philip. \& Gary Amstrong, 2008. Prinsip-prinsip Pemasaran. Edisi 12 Jilid I. Jakarta : Erlangga.

Prinsip - Prinsip Pemasaran. Jakarta: PT. Indeks Kelompok Gramedia

Lenny. 2005. "Pengaruh kelengkapan produk, Lokasi terhadap keputusan pembelian diswalayan indomaret Medan". Skripsi. Medan : Fakultas Ekonomi. Universitas Sumatra Utara.
Peter, Olson. 2005. Consumer Behaviour\& Marketing Strategy. New York: McGraw-Hill.

Raharjani, Jeni. 2005. "Analisis F aktor faktor yang Mempengaruhi Keputusan Pemilihan Pasar Swalayan Sebagai Tempat Berbelanja (Studi Kasus Pada Pasar Swalayan di Kawasan Seputar Simpang Lima Semarang)" . Dalam Jurnal Studi Manajemen \& Organisasi, Vol. 2 No. 1 Hal 1-15.

Schiffman, Kanuk. 2008. Perilaku Konsumen. Edisi 7. Jakarta: PT. Indeks

Setiawati, Nonik. 2015. "Pengaruh Kualitas Produk, Kualitas Pelayanan dan Harga Terhadap Kepuasan Konsumen Rumah Burger". Skripsi. Universitas Negeri Medan.

Swastha, Basu. 2007. Azas-azas Marketing. Edisi 3. Yogyakarta : Liberty.

2005. Manajemen

Pemasaran. BPFE: Yogyakarta.

Tjiptono, F. 2008. Strategi Pemasaran. Edisi 3. Yogyakarta: Penerbit Andi.

http://www. Tokopedia.com 